\title{
A szimbolikus tér átalakulása az Euromajdan után: Kijev és Kárpátalja összehasonlítása ${ }^{1}$
}

\author{
ERŐSS ÁGNES² - KOVÁLY KATALIN ${ }^{3}$
}

\begin{abstract}
ABSZTRAKT
Az utóbbi évtizedek társadalomföldrajzi kutatásai behatóan foglalkoznak a köztér és a politika viszonyának elemzésével (Massey 1994, Mitchell 2003). Ezen kutatások feltárták, hogy a város köztérnevekből, szobrokból és emlékművekből álló szimbolikus tere egy-egy politikai fordulat alkalmával jelentősen átalakul (Light 2004).

Az Euromajdant követően, 2015-ben került elfogadásra Ukrajnában az ún. „kommunizmustalanító törvénycsomag", amely minden korábbinál átfogóbban rendelkezett a szovjet múlt szimbólumainak közterekből való kötelező számüzéséről. A dekommunizáció kiterjedt a település- és köztérnevek mellett a városi tér egyéb elemeire, jelentösen átformálva azok arculatát.

Jelen kutatás homlokterében a dekommunizáció térbeli vonatkozásainak vizsgálata áll. Célunk annak áttekintése, hogy a dekommunizáció nyomán milyen fó változások következtek be egyrészt az ukrán fövárosban, Kijevben és ezzel párhuzamosan az ország politikailag és gazdaságilag egyaránt perifériáján lévő Kárpátalja település- és köztérneveiben. Vizsgálatunk másik célja - Ungvár, a Beregszászi járás és Beregszász város példáján - rávilágítani arra, hogy a dekommunizáció nyomán hogyan valósul meg a lokális emlékezet térbeli reprezentációja.
\end{abstract}

KULCSSZAVAK: dekommunizáció, Kárpátalja, Kijev, szimbolikus tér, utcanév, köztér

\section{ABSTRACT}

\section{Reconfiguration in Post Euromaidan symbolic landscape: comparison of Kyiv and Transcarpathia}

The relation between power and public space has been one of the main interest of geographical research in the last decades (Massey 1994, Mitchell 2003). Researches have illustrated that following a regime change, the symbolic space of the city - compiled of street names, statues and monuments - usually gets reconfigured. Following the Euromaidan, in 2015, the laws on decommunization were accepted in Ukraine, which disposed more comprehensibly than ever

\footnotetext{
${ }^{1}$ A kutatást az MTA 2017. évi, NKF-2017/4 számú mobilitási támogatása tette lehetővé, amelynek címe „Regionális folyamatok és globális kihívások Ukrajnában és Magyarországon a 2008-as válság óta”.

${ }^{2}$ Magyar Tudományos Akadémia, Csillagászati és Földtudományi Kutatóközpont, Földrajztudományi Intézet,Tudományos segédmunkatárs

${ }^{3}$ Magyar Tudományos Akadémia, Csillagászati és Földtudományi Kutatóközpont, Földrajztudományi Intézet, Fiatal kutató
} 
www. metszetek.unideb.hu

\section{TEMATIKUS TANULMÁNYOK - Kárpátalja társadalma}

before the banishment of Communist symbols from the public space. The decommunization besides toponymy, entangled other elements of public space resulting in major shifts the urban landscape as well.

Main interest of present paper is to study the major shifts in symbolic landscape in the capital, Kyiv and compare it to the processes that have taken place in the westernmost periphery of the country, Transcarpathia. Based on the examples of Uzhhorod, Berehove raion and Berehove, our further aim is to shed light on the role of locality and how local memory is represented in public space.

KEYWORDS: Decommunization, Transcarpathia, Kyiv, symbolic landscape, street name, public space

\section{Bevezetés}

A köztér felfogható olyan arénaként, mely alanya, ugyanakkor tárgya is a legkülönfélébb egyéni, csoport és hatalmi szereplők, ideológiák reprezentációjának. A köztérben való láthatóság, illetve a köztér egyes elemeinek megjelölése, saját képre formálása (például szobrok eltávolítása vagy elhelyezése) felfoghatók olyan szimbolikus eszközökként, amelyek az adott hatalom/egyén/csoport terület felett gyakorolt kontrollját, hatalmi potenciálját fejezik ki (Bourdieu 1989). Következésképpen a hatalomváltások gyakran együtt járnak a köztér átalakulásával, amennyiben a hatalom új birtokosa tudatosan igyekszik a teret az ideológiájával harmonizáló szimbólumok révén saját képére formálni (Hobsbawn 2015, Barna 2000). Ezen szimbolikus politikák különböző formát ölthetnek: az előző hatalom emlékeinek eltüntetését rendszerint az új hatalom szimbólumainak köztérbe helyezése követi, de esetenként a korábbi szimbólumok újraértelmezése vagy azok kisajátítása is megtörténhet (Harrison 1995).

A köztér szimbolikus tartalmaival valamint a szimbolikus politikákkal és térfoglalási eljárásokkal széleskörű szakirodalom foglalkozik, mely a különböző földrajzi terekben (például Kezer 2009, Yeoh 1992, Njoh 2017, Kliot - Mansfield 1994) és történelmi időszakokban (van der Wusten 2000, Atkinson - Cosgrove 1998, Azaryahu - Kook 2002, Harvey 1979) vizsgálja, hogyan alakítja és használja a politika a földrajzi teret, illetve a közteret fennhatóságának kifejezésére, illetve az aktuális ideológia megjelenítésére. A települések köztérnevekből, szobrokból és emlékművekből álló szimbolikus tere ${ }^{4}$ egy-egy politikai fordulat alkalmával jelentősen átala-

\footnotetext{
${ }^{4}$ Írásunkban a szimbolikus tér fogalmat használjuk, mivel az angol nyelvű szakirodalomban használt symbolic landscape magyar fordítása (szimbolikus tájkép) véleményünk szerint nem ugyanazt jelenti, illetve tekintve a magyar földrajz angolszásztól eltérő sajátosságait, félreértelmezésre adhat okot. Szimbolikus térként értelmezzük a tér köztérnevekből, szobrokból, emlékművekből, emléktáblákból álló hálóját. Ezen, a fizikai térben létező, megfogható elemek mellett értelmezésünkben a szimbolikus tér magába foglalja mindazokat a politikákat, cselekvéseket, rítusokat, amelyek a térhez kapcsolódnak és a térben nyilvánulnak meg. A szimbolikus tér meghatározásáról illetve a magyar nyelvű fogalomhasználat problematikájáról lásd bővebben Erőss 2018.
} 


\section{TEMATIKUS TANULMÁNYOK - Kárpátalja társadalma}

kul (Light 2004). Jelen írás tárgyához legszorosabban az egykori keleti blokk országaiban - jórészt az 1990-es évek első felében lezajlott - dekommunizációt elemző tanulmányok kapcsolódnak. Bukarest (Light 2004), Budapest (Palonen 2008, Pótó 2003) vagy Berlin (Till 1999, Azaryahu 1997) esetében egyaránt megfigyelhető, hogy a kommunista ideológia és múlt emlékeinek eltávolítása együtt járt a nemzetfogalom és a nemzeti identitás újraértelmezésével, és annak köztérben megnyilvánuló reprezentációjával. Ezen kutatások továbbá felhívják a figyelmet arra, hogy az átalakulás az emlékezés és a felejtés dinamikájában formálódik: az aktuális, jelenbeli élethelyzet- és körülmények alapvetően befolyásolják azt, ahogyan és amire/akire emlékezünk a múltból. Fontos megjegyezni, hogy az egyéni emlékezethez hasonlóan az emlékezetpolitika is szelektív jellegú, vagyis a múlt eseményei, alakjai közül az aktuális hatalom számára kívánatosak kerülnek be a nemzeti ünnepek, emléknapok, nemzeti hősök sorába. (Azaryahu 1996, Nadkarni 2003, Palonen 2008, Diener Hagen 2013). Az Euromajdan és az azt követő társadalmi-politikai események bemutatására illetve értékelésére számos tanulmány és kötet tett kísérletet az elmúlt években (Olszański 2016, Hale - Orttung 2016. Kulyk 2014, 2016, Fedinec 2016, Shveda - Park 2016, Kuzio 2015). ${ }^{5}$

Írásunkban az Euromajdant mint politikai értelemben vett választóvonalat, hatalomváltást értelmezzük, amely nyomán a korábbi oroszbarát, a szovjet múlt emlékeiből is táplálkozó emlékezetpolitikát az ukrán nemzeti tartalmak újradefiniálása és a nacionalista diskurzus előtérbe kerülése jellemzi. Függetlenül attól, hogy mennyiben azonos vagy eltérő az Euromajdan előtti és az azt követő politikai vezetés személyi összetétele vagy a hatalomgyakorlás módja, a szimbolikus politikák, a nemzeti tartalmak köztérben való megjelenítése, illetve az emlékezetpolitika szempontjából korszakhatárnak tekintjük az Euromajdant és a 2015-ben elfogadott dekommunizációról rendelkező törvénycsomagot.

Az Euromajdant követően hatalomra került ukrajnai politikai vezetés igyekezett körülhatárolni saját legitimitásának formai és tartalmi kereteit, amelyben a nemzetfogalom és a nemzeti tartalmak újraértelmezése kiemelt szerepet kapott (Tsyba 2017). A nemzet újradefiniálásában a Fredrik Barth (1969) által leírt cso-

\footnotetext{
${ }^{5}$ Euromajdan névvel azt a tüntetéssorozatot illetik, amely 2013. november 21-én indult a kijevi Függetlenség téren (Majdan Nezalesnosztyi). A tiltakozást közvetlenül Ukrajna Európai Unióval kötendő társulási egyezménye aláírásának elhalasztása váltotta ki, amely nem csupán Ukrajna euroatlanti integrációjának jövőjét érintette, hanem az Oroszországhoz füződő kapcsolatainak erősítését is jelentette (Kulyk 2014). A kezdeti európai integráció melletti tüntetés fokozatosan hatalomellenessé vált, az Euromajdan így az egész Méltóság forradalmának nevezett mozgalomra is vonatkoztatható (Fedinec 2016). Az azóta eltelt időszakban számos politikai-gazdasági-társadalmi változás zajlott Ukrajnában, amelyek eredményei és megítélése vitatott (Olszański 2016, Hale - Orttung 2016). Ezen események és viták ismertetése nem képezi tárgyát írásunknak. A kutatók között abban sincs egyetértés, hogy minek tekinthető az Euromajdan: egyesek tüntetésként (protest), eseményként (event) említik (Kulyk 2014, Kuzio 2015), míg máshol forradalomként hivatkoznak rá (Shveda - Park 2016).
} 


\section{TEMATIKUS TANULMÁNYOK - Kárpátalja társadalma}

portképzés dinamikája fedezhető fel, amely szerint a társadalmi csoportok a belső kohézió és a külvilágtól, az egyéb csoportoktól való elhatárolódás dialektikus folyamatában formálódnak. Az Euromajdan utáni Ukrajna esetében az előbbi egyrészt új nemzeti hősök teremtésében vagy korábbiak átértelmezésében érhető tetten, de ebben a viszonyrendszerben kerül értelmezésre a Méltóság forradalmának halálos áldozatokat követelő eseményei, a Krím-félsziget annexiója és a 2014 óta eszkalálódó kelet-ukrajnai fegyveres konfliktus is. Amíg a költők, Tarasz Sevcsenko vagy Leszja Ukrajinka korábban is tagjai voltak az ukrán nemzeti panteonnak, addig az utóbbi években megfigyelhető a kozák hetmanok ${ }^{6}$ (pl. Dorosenko, Kalnisevszkij) vagy egyéb, az I. vagy II. világháború idején harcolók beemelése a nemzeti hősök közé. Fontos megjegyezni, hogy az Euromajdan összecsapásai során elesettek, az ún. Mennyei Század (Небесна Сотня) tagjai (Yurchuk 2014) vagy a jelenleg is zajló kelet-ukrajnai harcokban elesett katonák (ATO katonák) ${ }^{7}$ igen hamar beépülnek a hatalom emlékezetpolitikájába és mára a fényképeikből készített tablók a köztér megkerülhetetlen elemei (lásd 1., 3. fotó). Egy nemrégiben készült felmérésből tudható, hogy a közelmúlt áldozatainak gyors glorifikálása az ukrán társadalom széles rétegei számára is elfogadott (Kulyk 2016). Fontosnak tartjuk idézni Fedinec Csilla 2016-os tanulmányát is, amelyben egyrészt megállapítja, hogy az ukrán „történelem elbeszélése gyakran alapszik mártírológián vagy olyan ellenségképen, amely az országon belüli és kívüli jelenkori politikai erőkre asszociál.“ Másrészt kiemeli, hogy a történelem interpretálása része a politikai küzdelmeknek és a politikai érdekek mentén kialakított nemzetkoncepcióknak (Fedinec 2016: 30).

A más csoportoktól való elhatárolódás, amely ugyancsak a belső csoportkohézió erősítését hivatott szolgálni, a gyakorlatban elsősorban az Oroszországtól való elszigetelődést jelenti. A folyamat Ukrajnában a Szovjetunió felbomlása után vette kezdetét (Kuzio 1998) majd a „Leninhulláskor" ${ }^{8 ”}$, új lendületre kapott (Kobchenko 2016, Kiridon 2017, Pokatayev 2018) és számos feszültséggel és ellentmondással teli (Kulyk 2014, Fedinec - Csernicskó 2016). Mindezen komplex folyamatot tükrözi az ukrán parlament által 2015. április 9-én elfogadott, Porosenko ukrán elnök által 2015. május 15-én aláírt ún. „kommunizmustalanító törvénycsomag”, mely

${ }^{6}$ Yekelchyk (2015) megjegyzi, hogy a kozáksághoz kapcsolódó kitalált tradíció a nyugat ukrajnai területeken a 19. század vége óta jelen van.

${ }^{7}$ ATO, azaz Anti Terrorist Operation = Антитерористична Операція. A 2014 óta zajló kelet-ukrajnai fegyveres konfliktust 2018 áprilisáig az ukrán fél hivatalosan ezzel a névvel illete (azóta: egyesített erők művelete, ukránul: Операція об’єднаних сил), kerülve a háború szó használatát. Az Ukrajna területén harcoló ellenséges alakulatokat hivatalos szóhasználatban terroristáknak nevezik. Írásunkban - az egyszerűség kedvéért - ATO katonákként vagy ATO harcosokként kerülnek említésre a hibrid háborúban harcolók vagy elesettek.

${ }^{8}$ Ukránul: Ленінопад. A Lenin szobrok tömeges ledöntése a Méltóság forradalma után. 2014 folyamán több mint 500 Lenin szobrot távolítottak el/döntöttek le országszerte (Kiridon 2017).

${ }^{9}$ Fedinec Csilla és Csernicskó István 2016-os tanulmányukban a „kommunizmustalanító csomag” kifejezést használja (Fedinec - Csernicskó 2016: 73). Írásunkban a dekommunizációs törvény kifejezést használjuk. 


\section{TEMATIKUS TANULMÁNYOK - Kárpátalja társadalma}

összesen négy törvényt foglal magába. Vizsgálatunk tárgyát „A kommunista és a nemzetiszocialista totalitárius rezsimek elítéléséről és jelképeik propagandájának betiltásáról" c. törvény ${ }^{10}$ (mely a négy dekommunizációs törvény egyike) nyomán végrehajtott gyakorlati intézkedések képezik, amelyek jelentős mértékben átalakították az összehasonlítani kívánt települések nyelvi és szimbolikus tájképét.

Tanulmányunkban áttekintést kívánunk nyújtani a dekommunizációs törvények területi, térbeli vonatkozásairól Kijev illetve a kiválasztott kárpátaljai települések, közigazgatási egységek példáján. Célunk rávilágítani arra, hogy milyen eltérések figyelhetőek meg a szimbolikus politika különböző mintázataiban az ukrán központi hatalom helyszínén Kijevben, valamint a kelet-ukrajnai harcoktól távol fekvő, az Ukrajnában politikailag és gazdaságilag is perifériális helyzetben lévő Kárpátalján (Jordan - Klemenčić 2003).

\section{A vizsgálati terepek bemutatása, módszertan}

A vizsgálat egyik színtere Ukrajna fővárosa, a csaknem 3 millió fős lakossággal rendelkező Kijev, továbbá Kárpátalja megye székhelye Ungvár (115 ezer fő), ahol az ukrán többség mellett $(78 \%)$ az orosz $(9,6 \%)$ és a magyar $(6,9 \%)$ népesség aránya is számottevő (Molnár - Molnár D. 2005). A harmadik település Beregszász (24 ezer fő), ahol többé-kevésbé kiegyenlítettek a nemzetiségi arányok: 48,1\% a magyarok részesedése, 38,9\% az ukránoké, míg 5,4\% az oroszoké. A városok mellett röviden kitérünk a dekommunizáció nyomán a Beregszászi járásban bekövetkezett változásokra is, mely Kárpátalja (és Ukrajna) egyetlen magyar többségú járása (a magyarok a népesség 76,1\%-át adják) (Molnár - Molnár D. 2005).

Munkánkban kiemelten foglalkozunk a köztérnevek változásaival, tekintve, hogy az utcák el-, vagy átnevezése egyike a leggyakrabban alkalmazott szimbolikus politikáknak. Az utcanevek szimbolikus erejét hétköznapiságuk adja: mivel egyértelmű, praktikus funkcióval rendelkeznek (elősegítik a tájékozódást) ezért az emberek magától értetődően használják ezeket (David 2013). Ígya beszélők - akár akaratuktól függetlenül - a hivatalos utcanevek kiejtése által az aktuális hatalmi narratívát ültetik át hétköznapi beszédszituációkba. Következésképpen az utcanevek "közvetítenek a politikai elitek és az átlagemberek között" (Azaryahu 2009: 54). A kommemoratív utcanevek különösen fontos eszköznek bizonyulnak a város szimbolikus tájképében: az utcanévben megörökített (vagy onnan eltüntetett) személy az aktuális hatalom történelem és/vagy nemzetfelfogását közvetíti, így az utcanevek révén lehetővé válik, hogy egyfajta hatalmi narratíva épüljön be a társadalmi élet intimebb szféráiba és interakcióiba (Azaryahu 1996).

\footnotetext{
${ }^{10}$ Fedinec - Csernicskó 2016.
} 


\section{TEMATIKUS TANULMÁNYOK - Kárpátalja társadalma}

Kutatásunk során elsőként létrehoztunk egy adatbázist, amelyben összegyűjtöttük a köztér és településnevek változására vonatkozó adatokat. Kijev vonatkozásában az adatok egy részét az Ukrán Nemzeti Tudományos Akadémia Földrajzi Intézete által rendelkezésünkre bocsájtott lista képezte, amelyet interneten elérhető forrásokkal egészítettünk ki. ${ }^{11} \mathrm{~A}$ Kárpátalján történt átnevezéseket ukrán és magyar nyelvű helyi, az interneten elérhető dokumentumok és sajtóhírek alapján összegeztük. ${ }^{12} \mathrm{~A}$ köztérnévváltozásokat tartalmazó adatbázisokat ezután több szempontból elemeztük. Az utcaneveket egyrészt etnikai vonatkozásuk alapján minősítettük, tehát azok a történelmi személyiségek, művészek vagy események, akik vagy amelyek az ukrán történelemhez, kultúrához kapcsolódnak (pl. Sevcsenko) ukrán minősítést kaptak, akik a magyarhoz következésképpen magyart (pl. Ady). Az etnikai jelentéssel nem bíró nevek etnikailag semlegesként kerültek az adatbázisba (pl. Virág) (Erőss - Tátrai 2010). Az értékelés során külön figyelmet fordítottunk a személynevek számbavételére, tekintve, hogy ezek bírnak a legnagyobb szimbolikus erővel. Az adatbázis elemzése mellett 2016 májusa és 2017 szeptembere között Kijevben és Kárpátalján több ízben végeztünk terepkutatást is. Ennek révén munkánkat terepi megfigyeléssel is kiegészítettük, amelynek eredményeként a köztérben zajló változásokat dokumentáló fotók is fontos részét képezik cikkünknek.

\section{A dekommunizációs törvény Ukrajnában}

A kommunizmus hagyatékának minden korábbinál szélesebb körű száműzését „A kommunista és a nemzetiszocialista totalitárius rezsimek elítéléséről és jelképeik propagandájának betiltásáról" című törvény mondja ki. A törvény - egyebek között - elrendelte a szovjet totalitárius rendszer szimbólumainak eltávolítását a közterekről, miközben előírta a 20. században az ukrán függetlenségért harcolókra való megemlékezést (Riabchuk 2016). A rendelkezés részletesen meghatározta a betiltandó önkényuralmi jelképek, szimbólumok, intézmények és elnevezések körét (Fedinec Csernicskó 2016). Végrehajtásával az Ukrán Nemzeti Emlékezet Intézetét bízták meg (Інститут Національної Пам'яті; a továbbiakban UNEI), amely elkészített és kiadott egy 520 személynevet tartalmazó listát. ${ }^{13} \mathrm{Az}$ ezen szereplő személyekről elnevezett településeket, utcákat és köztereket a törvény értelmében kötelező volt átnevezni. A listára főként a szovjet korszakhoz köthető történelmi és politikai szereplők (pl. Molotov, Marx, Lenin, Brezsnyev, Osztrovszkij) kerültek, de megtalálhatóak

\footnotetext{
${ }^{11} \mathrm{Az}$ adatforrások pontos hivatkozását lásd az 1. táblázatnál.

${ }^{12}$ A sajtóhírek hivatkozásait lásd a tanulmány további alfejezeteinél, illetve a felhasznált irodalom „Internetes források” részénél.

${ }^{13}$ UNEI: Список осіб, які підпадають під закон про декомунізацію. Elérhető: http://www.memory.gov.ua/publication/spisok-osib-yaki-pidpadayut-pid-zakon-pro-dekomunizatsiyu. Letöltés: 2017. 11. 15 .
} 


\section{TEMATIKUS TANULMÁNYOK - Kárpátalja társadalma}

voltak rajta művészek, illetve kevésbé ismert forradalmár diákok, gyári dolgozók is. A törvény hatálya kiterjedt azokra a fogalmakra, szimbólumokra is, amelyek a döntéshozó értelmezése szerint a szovjet időszakra emlékeztetnek (pl. Komszomol, Októberi, Vörös Hadsereg stb.). A gyakorlatban a kommunizmus vagy kommunista gyűjtőfogalom használatát és alkalmazását jelentős mértékben befolyásolta a 2014 óta elmérgesedett orosz-ukrán viszony. Ezt példázza az egykori szovjet űrhajósnő Tereskova esete, akinek az ukrajnai közterekről való eltüntetése inkább a jelenlegi orosz Dumában elfoglalt képviselői szerepének tudható be, mintsem a Szovjetunió idején elért pozíciójának. A dekommunizáció egyes értékelések szerint valójában úgy értelmezhető, mintegy jó alkalom a de-russzifikáció végrehajtására (Kozyrska 2016).

Hasonló folyamat, vagyis a kommunista múlt és emlékek köztérből való eltávolítása a többi volt szocialista országban az 1990-es években ment végbe, felemás sikerrel (Light 2004, Palonen 2008). A kommunista jelző relativizálásával újabb és újabb személyek, történelmi események kerülhetnek fel a dekommunizációs listára, ami igazolja a köztérnevek váltakozásának aktuálpolitikai beágyazottságát (Palonen 2012). Másrészt a szovjet múlt felszámolása nemcsak a valamitől való elhatárolódás aktusa, de a valamihez való tartozás szimbólumaként is megjelenhet, ahogy ezt a tallini a II. világháborúban elhunyt szovjet katonáknak emelt hősi emlékmű elköltöztetése kapcsán Melchior és Visser (2011) megjegyzi.

Ukrajnában a dekommunizációs törvény térbeli következményeit a szovjet/orosz múlthoz kapcsolódó szobrok (Fedinec - Csernicskó 2016), emlékművek, településés egyéb köztérelnevezések eltüntetésében érhetjük tetten. Az UNEI honlapja szerint $^{14} 2016$ júliusáig 987 települést és 25 járást neveztek át a fentebb megnevezett törvény értelmében, melyek túlnyomó része Ukrajna keleti megyéiben találhatók. Közöttük volt például Dnipro (korábban Dnipropetrovszk), Horisni Plavni (korábban Komszomolszk) és Kropivnickij (korábban Kirovográd) városa is. Az átnevezett települések közül 133 az 1917-es októberi orosz forradalomhoz, 108 Lenin, 69 Petrovszkij, 48 Kirov, 35 pedig Csapajev nevéhez füződött.

A dekommunizációs törvény végrehajtása Ukrajnában több lépcsőben zajlott. A fentebb említett, UNEI által összeállított listában szereplő személyekről elnevezett utcákat, tereket és más helységneveket 2015. november 21-ig kötelező volt megváltoztatni. A névváltoztatásról (vagyis arról, hogy mi legyen a köztér új neve) a helyi tanácsok (járási/városi/községi) dönthettek. Az új elnevezésekre javaslatot tehettek az adott település lakosai, civil szervek, ukrán vagy külföldi állampolgárok, amit a helyi szintű bizottságok bíráltak el. A megadott határidő után (2016.02.22.) a megye vezetőjéhez került a közterek átnevezésének joga. ${ }^{15} \mathrm{~A}$ megváltoztatott utca- és

${ }^{14}$ Декомунізація. Elérhető: http://memory.gov.ua/page/dekomunizatsiya-0 (Letöltés: 2018.06.11.)

${ }^{15}$ Sajtóértesülések szerint Kárpátalja kormányzója, Hennadij Moszkal volt az első az ukrajnai megyei kormányzók közül, aki elkezdte ezen átnevezéseket.(Novynarnia.com: Москаль перейменував 20 вулиць на Закарпатті на честь загиблих в АТО: https://novynarnia.com/2016/04/05/moskal-pereymenuvav-20-vulits-na-zakarpatti-na-chest-zagiblih-v-ato/ (Letöltés: 2016.04.05.) 


\section{TEMATIKUS TANULMÁNYOK - Kárpátalja társadalma}

köztérneveket nem volt szükséges kötelező jelleggel átvezetni a lakosok hivatalos okmányaiba, ezek anélkül is érvényesek maradtak (UNEI 20176, Kozyrska 2016)

Érdekesség, hogy helyi szinteken több olyan köztér átnevezéséről is döntöttek, melyek nem szerepeltek a kötelezően megváltoztatandó nevek listáján. Ilyen például az ukrán fővárosban található egykori Moszkva sugárút, melyet a kijevi városvezetés Sztepan Bandera ${ }^{17}$ sugárútra keresztelt. Bandera megítélése heves vitákat vált ki, mind ukrán, mind nemzetközi körökben, az ukrán történelem egyik legmegosztóbb személyisége. ${ }^{18}$ Vezetésével kiáltották ki 1941. június 30-án Lembergben (Lvivben) a független Ukrajnát, a német megszállás miatt azonban ez a lépés sikertelen maradt. Amíg Nyugat-Ukrajnában nemzeti hősnek tartják (Wylegała 2017), addig a keleti országrészben náci kollaboránsként tekintenek rá. Éppen ezért Kijev egyik legforgalmasabb sugárútjának, a Moszkva sugárútnak átnevezése Bandera sugárútra jól példázza a jelenlegi politikai vezetés nemzetépítését jellemző dialektikát: egyszerre erősíteni a belső kohéziót egy, a nyugati országrészben elismert személyiség köztérben való szerepeltetésével, miközben ez a lépés az elhatárolódást is jelenti azoktól, akik számára Bandera nem elfogadható. Mintegy az országot jellemző kelet-nyugati megosztottság (Karácsonyi et al. 2014) egyik indokátoraként is tekinthetünk a Bandera szobrok és utcanevek megjelenésére: Banderáról elnevezett köztereket és szobrokat kizárólag Kijevtől nyugat-északnyugatra találhatunk (Kobchenko 2016). Fontos azonban kiemelnünk, hogy a legnyugatibb megyében, Kárpátalján egyetlen utcát sem neveztek el róla, illetve egyetlen emlékművét sem találjuk (Fedinec - Csernicskó 2016).

A dekommunizáció végrehajtása Ukrajnában nem ütközött jelentősebb társadalmi ellenállásba. Sőt, felmérések szerint a lakosságot csak mérsékelten foglalkoztatta a dekommunizáció. Ennek okaként Shevel három tényezőt említ. Elsőként az Oroszországgal 2013-2014 óta fennálló konfliktus megerősítette az ukrán nemzettudatot és a patrióta érzelmek nagyban megkönnyítették a kommunista múlttal való végleges szakítást. Másrészt a dekommunizáció hatálya alá tartozó változások több helyen spontán lezajlottak, részben az 1990-es évek óta, részben az Euromajdan eseményeivel egyidőben (lásd feljebb a Leninopadot). Harmadrészt a helyi lakosokat gyakran sokkal inkább a dekommunizáció anyagi vonatkozásai aggasztották.

${ }^{16}$ UNEI: http://memory.gov.ua/news/faq-use-shcho-vi-khotili-diznatisya-pro-dekomunizatsiyu (Letöltés: 2017. 11.15.)

${ }^{17}$ Viktor Juscsenko, a „narancsos forradalommal” hatalomra kerülő elnök, 2010-ben Banderát Ukrajna hősévé nyilvánította, amivel nemzeti konszenzus nélkül beemelte őt az ukrán nemzeti hősök panteonjába. Később az elnöki rendeletet eltörölték, arra hivatkozva, hogy Bandera soha nem volt ukrán állampolgár (Fedinec - Csernicskó 2016).

${ }^{18}$ Bandera vitatott megítélésének mintegy bizonyítékaként említik, hogy 25 évvel a rendszerváltás után sem létezik alapos monográfia róla (Fedinec - Csernicskó 2016, Yekelchyk 2015). Egy felmérés eredményei szerint Bandera megítélése javult 2012-2014 között, de még mindig többen vélik negatív szereplőnek, mint pozitívnak (Kulik 2016). Yekelchyk (2015) az ukrán diaszpóra szerepére is felhívja a figyelmet a vitában. 


\section{TEMATIKUS TANULMÁNYOK - Kárpátalja társadalma}

A mérsékelt érdeklődés tetten érhető abban is, hogy általában párszáz lakos vett részt az új elnevezésekről döntő online szavazásban és még kevesebben javasoltak új neveket (Shevel 2016).

A továbbiakban a dekommunizációs törvény gyakorlati végrehajtásának eredményeit és azok területi sajátosságait kíséreljük meg bemutatni a különböző szinteken lévő, eltérő kulturális és történelmi örökséggel bíró, etnikailag vegyes összetétellel rendelkező települések példáján.

\section{Változások Kijev szimbolikus tájképében}

Kijevben a kommunista vonatkozású köztérnevek száműzését célzó első átnevezési hullám 1991-1996 között zajlott. Ekkor főként a központi utcákat és tereket nevezték át, mely a fővárosi köztérnevek csupán 1\%-át jelentette (körülbelül húsz utca). A függetlenség első éveiben zajló átnevezésekkel ellentétben az Euromajdan utáni köztérnévváltozások már az egész fővárost érintették (Males 2016/a). A Kijevben található 2715 utca és tér közül 2016 végéig összesen 152 kapott új nevet. Az új utcanevek csaknem kétharmada, 99 személynévre változott. Ezek túlnyomó többsége (89) ukrán vonatkozású személyiségnek, a legtöbb esetben az ukrán történelem és kultúra kiemelkedő alakjának állít emléket.

Az új utcaneveket vizsgálva a névadás két jellemzojét emelhetjük ki, amelyek visszatükrözik az Euromajdan utáni ukrajnai politikai vezetés fentebb bemutatott emlékezetpolitikájának és nemzetfelfogásának preferenciáit. Egyrészt megfigyelhető a korábban ellentmondásos megítélésük miatt csak az ország egyes területein (jellemzően Nyugat-Ukrajnában) tisztelt hősök megjelenése Kijev utcanevei között (például Bandera). Másrészt mind az új köztérnevek mind a köztéri szobrok, emlékművek tanúsítják, hogy az Euromajdan áldozatai a nemzet új hőseiként kerültek be a hivatalos emlékezetpolitikába. A jelenlegi ukrán vezetés a Méltóság forradalmának is nevezett Euromajdan halálos áldozatokat is követelő, erőszakos eseményei után került hatalomra. Az áldozatokról való megemlékezés, alakjuk heroizálása és beemelése a nemzeti hősök sorába így mintegy hozzájárul az aktuális hatalom legitimitásának kialakításához, növeléséhez. A Majdanon elesettek, azaz a Mennyei Század-ként emlegetett áldozatok tablóba rendezett fotóival, mécsesekkel, virágokkal díszített emlékműve ma már a kijevi városkép szerves része (1. fotó). Ez az eleven emlékmüként (Erőss 2016) is felfogható kegyeleti hely a város egyik központi fekvésű utcáján található. Az utcát, amely a Függetlenség térről (Майдан Незалежності), a harcok színteréről a kormányzati negyed, így az országgyülés épülete felé vezet, a Mennyei Század Hősei utcává keresztelték (2. fotó). A Mennyei Század fotói, az ukrán nemzeti színekkel ábrázolt angyallal díszített tabló országszerte sokfelé megtalálható, mintegy a nemzeti gyász és összetartozás központi szimbólumaként is értelmezhető (3. fotó). 


\section{TEMATIKUS TANULMÁNYOK - Kárpátalja társadalma}

A köztérnévváltozások térbeli vonatkozása kapcsán megemlítendő, hogy Kijevben az átnevezések ugyanúgy érintettek forgalmas sugárutakat (mint például a fentebb bemutatott egykori Moszkva sugárút), mint kisebb utcaközöket. A lecserélt nevek között találunk két magyar vonatkozású személynevet is: Gavró Lajosét, aki az UNEI honlapja szerint Kijev katonai parancsnoka volt 1919-ben a bolsevik megszállás idején, valamint Zalka Mátéét, aki a szovjet hatalom Ukrajnában való létrehozásának résztvevője volt. Előbbi a Jordanszka, ${ }^{19}$ utóbbi az Arhipenko Olekszander ${ }^{20}$ nevet kapta.

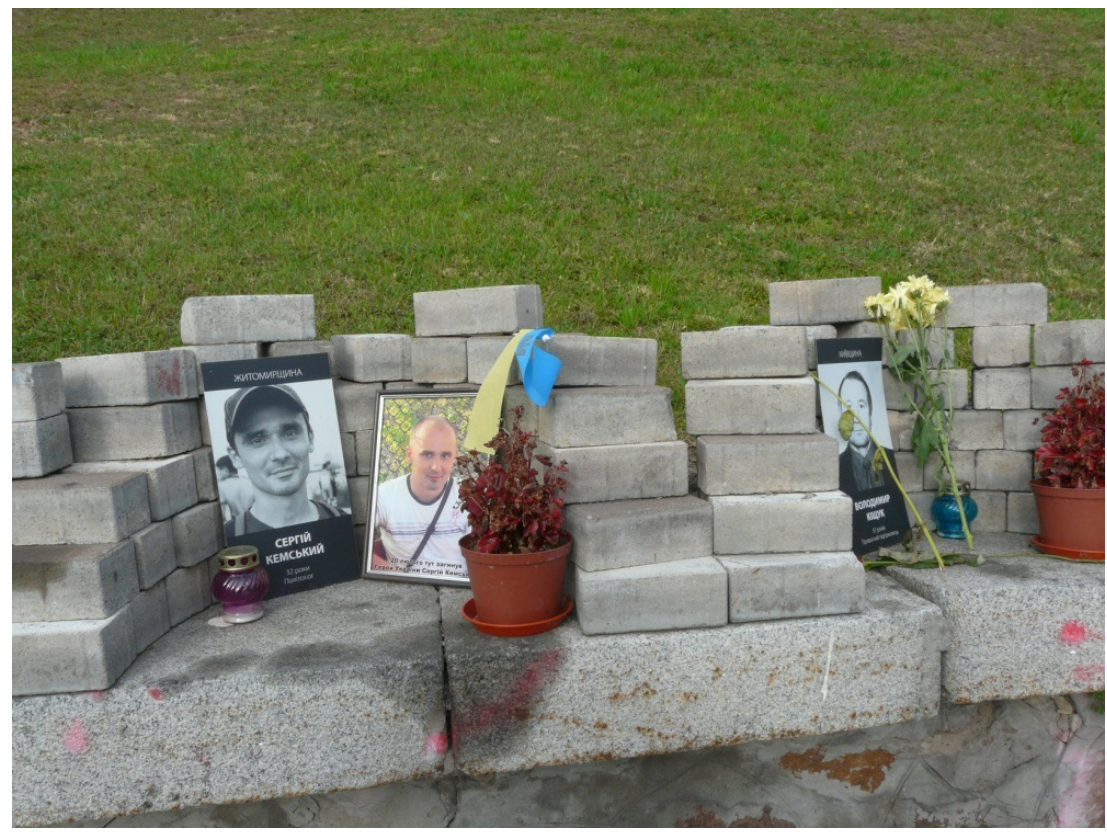

1. fotó. Részlet a Majdanon elesettek tiszteletére emelt emlékműből.

Az áldozat arcképe mellett rövid ismertető olvasható életéről (Kijev, 2016. szeptember) Fotó: Erőss Ágnes

\footnotetext{
${ }^{19}$ A Jordánszka-tó közelében található.
}

${ }^{20}$ Ukrán-amerikai szobrászművész. 


\section{TEMATIKUS TANULMÁNYOK - Kárpátalja társadalma}

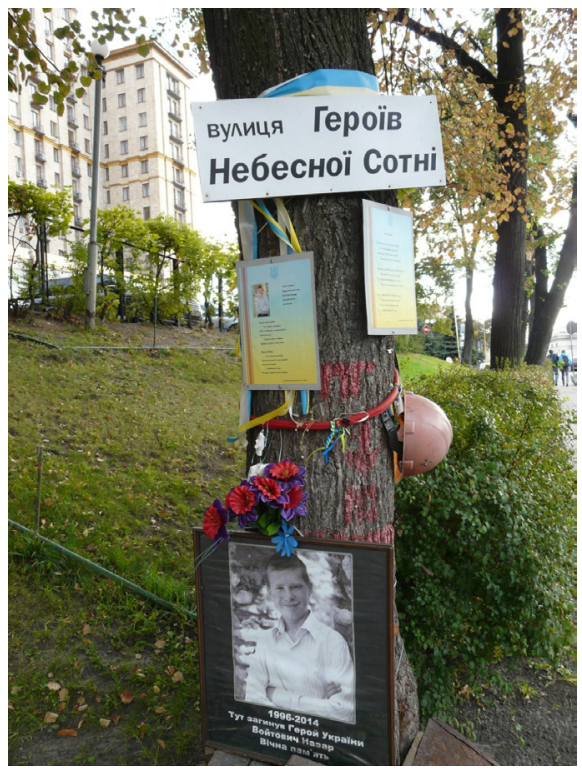

2. fotó. Utcanévtábla a Mennyei Század Hősei utca egy szakaszán. A fotók és virágok személyessé és élővé teszik a különböző emlékhelyeket (Kijev, 2016. szeptember) Fotó: Erőss Ágnes

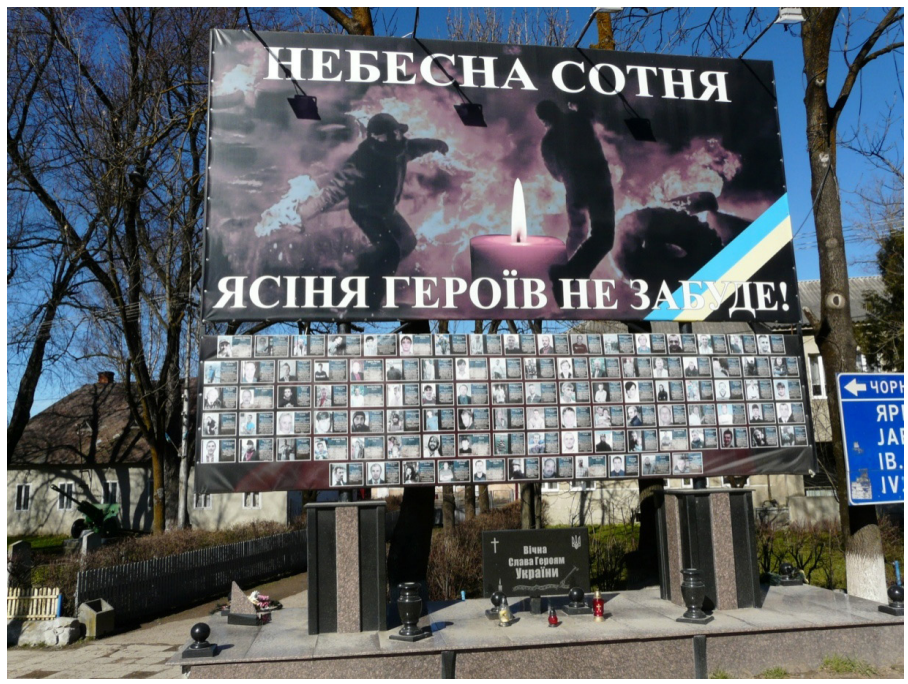

3. fotó. A Mennyei Századra emlékező tabló Körösmezőn. Hasonló tabló, különböző méretetekben sokfelé látható Ukrajna szerte (2016. április). Fotó: Erőss Ágnes 


\section{TEMATIKUS TANULMÁNYOK - Kárpátalja társadalma}

\section{Változások Kárpátalja szimbolikus tájképében}

Kárpátalján eredetileg két település (Zsovtneve a Huszti járásban és Komszomolszk a Técsői járásban), valamint 558 utca neve esett a dekommunizációs törvény hatálya alá (Fedinec - Csernicskó 2016). Az egyik átnevezendő település, Komszomolszk visszatért az 1947-ig használt Nyimecka Mokra (Németmokra) helységnévhez. Zsovtneve község helyi önkormányzata azonban megtagadta a névváltoztatást. Indoklásuk szerint a község nem az 1917-es pétervári puccsról, hanem a helyi, jellegzetesen sárgás színű agyagos talajáról kapta a nevét (lásd még Fedinec - Csernicskó 2016).

Elemezve a kutatásba vont településeken történt átnevezéseket (1. táblázat) elmondható, hogy a különböző hierarchikus szinteken (főváros, megyeszékhely, járási székhely) lévő városokban az átnevezett utcák arányai többé-kevésbé megegyezőek: Beregszászban ugyanúgy $5 \%$ körüli a dekommunizációs törvény hatálya nyomán módosított utcanevek aránya, mint a fóvárosban.

1. táblázat. A 2014 - 2016 között átnevezett közterek számának alakulása a kiválasztott kutatási terepeken (darab)

\begin{tabular}{|l|r|r|r|r|r|c|}
\hline & \multicolumn{2}{|c|}{ Kijev } & \multicolumn{2}{c|}{ Ungvár } & \multicolumn{2}{c|}{ Beregszász } \\
\hline $\begin{array}{l}\text { Közterület } \\
\text { jellege }\end{array}$ & Összes & Átnevezett & Összes & Átnevezett & Összes & Átnevezett \\
\hline Utca & 1962 & 113 & 518 & 26 & 147 & 7 \\
\hline Köz & 524 & 30 & 87 & - & 5 & - \\
\hline Tér & 55 & 5 & 19 & 1 & 6 & 1 \\
\hline Sugárút & 32 & 3 & 8 & - & 1 & - \\
\hline Sétány & 20 & 1 & 1 & - & 1 & - \\
\hline $\begin{array}{l}\text { Átnevezett } \\
\text { utcák } \\
\text { aránya (\%) }\end{array}$ & \multicolumn{2}{|c|}{5,8} & & 5 & & \\
\end{tabular}

Forrás: Az Ukrán Nemzeti Tudományos Akadémia Földrajzi Intézete által rendelkezésünkre bocsátott lista:

1. Suprunenko O: Міські депутати затвердили список вулиць та площ Берегова. Веregovo. Today http://beregovo.today/NewsOpen/id_news_281310 (Letöltés: 2017. 09. 19.)

2. Перейменування від Москаля: у Берегові нове ім>я навіть у вулиці Свободи. http://uzhgorod.net.ua/news/92585 (Letöltés: 2017. 09. 19.)

3. UNEI: Як перейменувати вулицю. http://www.memory.gov.ua/page/yak-pereimenuvati-vulitsyu (Letöltés: 2017. 10. 10) 


\section{TEMATIKUS TANULMÁNYOK - Kárpátalja társadalma}

A dekommunizáció kárpátaljai vonatkozásai közül az ATO katonákra emlékező utcaelnevezéseket emeljük ki. Egyrészt, mert sajtóbeszámolók alapján ${ }^{21}$ Kárpátalja az egyetlen olyan ukrajnai megye, ahol minden, a térségből származó elhunyt ATO katonáról megemlékeztek a köztérben, azaz utcát, parkot neveztek el róluk (vagy folyamatban van az átnevezés) több esteben emlékművön örökítették meg nevüket és arcképüket (4. fotó). Másrészt úgy véljük, hogy a településről származó elhunyt ATO katonákra való emlékezés hozzájárulhat a Kárpátaljától távol zajló háború helyi narratívájának kialakításához, megteremtve a helyi hősök panteonját. ${ }^{22}$

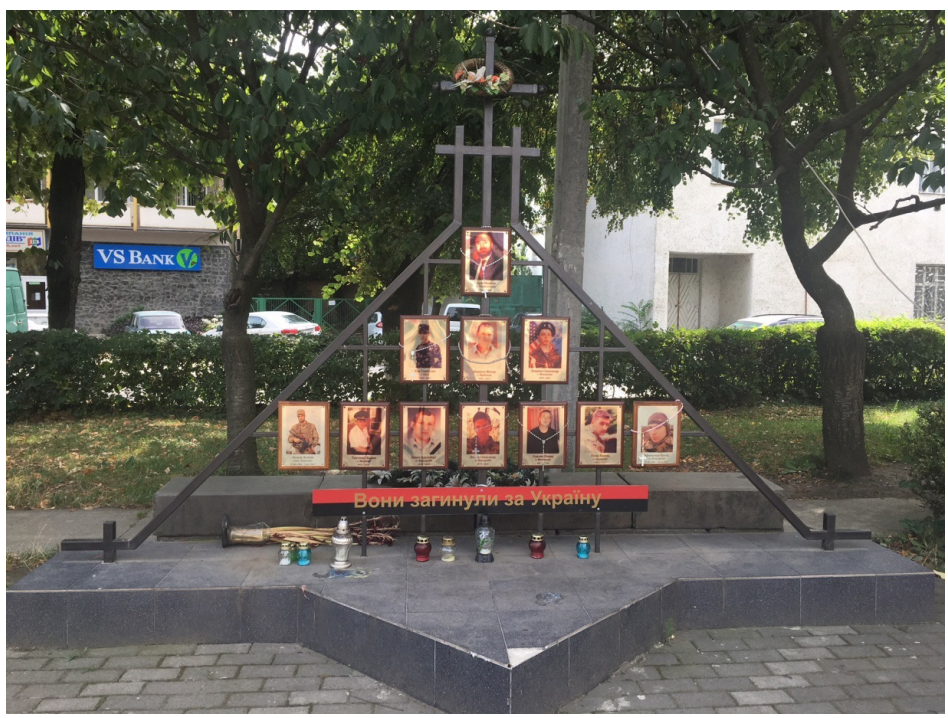

4. fotó. Az ATO katonák emlékműve, Nagyszőlős (2017. július) Fotó: Erőss Ágnes

Kárpátalján az ATO katonákról megemlékező átnevezések zöme 2016-ban zajlott le, a legtöbb a megyei kormányzó, Hennadij Moszkal határozata nyomán. 2017-ig összesen 36 ilyen átnevezés történt (ebből 9 Ungváron, három Beregszászon). Az esetek többségében korábban etnikailag semleges jelentésű utcák névadói lettek az elhunyt katonák (pl. Fő utca, Mező utca); mindössze 9 utcanév volt korábban szovjet vonatkozású. Fontosnak tartjuk megemlíteni, hogy minden kárpátaljai elhunyt ATO katona emlékét utcanévben örökítik meg azon a településen, ahonnan szárma-

${ }^{21}$ Novynarnia.com: Москаль перейменував 20 вулиць на Закарпатті на честь загиблих в ATO https://novynarnia.com/2016/04/05/moskal-pereymenuvav-20-vulits-na-zakarpatti-na-chest-zagiblih-v-ato/ (Letöltés: 2016.04.05.)

${ }^{22}$ Hasonlóan az országszerte megtalálható, a világháborúk helyi hősi halottainak, áldozatainak emlékhelyeihez. 


\section{TEMATIKUS TANULMÁNYOK - Kárpátalja társadalma}

zott. Ezáltal az ATO-ban, szülőföldjüktől távol elhunyt katonák helyi hősökké válnak. Mindez esetenként visszatükröződik a köztéri emlékezeti helyek kialakításában is. Beregszászon a város forgalmas pontján, a piac fala elé helyezték el az ATO áldozatainak emlékművét, amelynek központi alakjai az áldozatok felnagyított fényképei (6 fotó). Ezek mellett látható a Mennyei Század fentebb említett tablója is, azonban a méretbeli különbség és a térbeli elhelyezés módja a helyi áldozatokra irányítja a figyelmet, akik így (etnikumtól függetlenül) a teljes közösség hőseiként kerülnek megörökítésre.

Amennyiben adott településen nem volt elhunyt ATO katona akinek egy utcanévvel emléket állíthattak volna, akkor a dekommunizációs törvény hatálya alá eső utcák - a legtöbb esetben - az ukrán múlt kiemelkedő alakjairól kapták új nevüket. Ritkább esetben visszakapták egy-egy korábbi időszakban hivatalos, történelmi megnevezéseiket, esetleg semleges nevet kaptak.

\subsection{UNGVÁR}

Kárpátalja megyeszékhelyén összesen 26 utca és egy tér kapott új nevet, a legtöbb átnevezés 2016-ban történt. Az új köztérnevek közül 9 az Ungváron vagy az Ungvári járásból származó, az ATO-ban elesett katonák emléke előtt tiszteleg. További 12 új elnevezés az ungvári vagy kárpátaljai politikai, kulturális vagy tudományos élet kiemelkedő alakjaihoz (pl. Potusnyák, Hosovszkij, Komendar, Dobos), három pedig a térség történetéhez (pl. Klocsurák, Suhevics, Blisztiv) kötődik. ${ }^{23}$ Tehát mindössze három utca kapott olyan új nevet, melynek nincs közvetlenül helyi vonatkozása. Ebből két új név a Méltóság Forradalmáról emlékezik meg (Mennyei Század utca és a Majdan Hőseinek tere) míg egy harmadik a Krut Hőseinek utcája nevet kapta. ${ }^{24}$

Külön figyelmet érdemel, hogy Ungváron nincs központi megemlékezési hely az Euromajdan eseményeiről valamint annak áldozatairól. Egyetlen emlékmú található a megyeszékhely egy félreesőbb közterén, azonban ez sem kapcsolható közvetlenül a Méltóság Forradalmához. A 2016-ban állított emlékmü - mely az Ungvárról vagy az ungvári járásból származó, a kelet-ukrajnai harcokban elesett katonák neveit tar-

${ }^{23}$ Uzhgorod.net.ua: Перейменування від Москаля: у Берегові нове ім’я навіть у вулиці Свободи: http://uzhgorod.net.ua/news/92585 (Letöltés: 2017.09.19)

Andriiv B: Рішення про перейменування вулиць міста. Ужгородська міська рада: http://rada-uzhgorod.gov.ua/web/uploads/old_docs/rada/PR_pro_perejmenyv_vyluc_26.01.16.pdf (Letöltés: 2017.09.20.)

Ungvár város honlapja: В Ужгороді перейменували вулиці Джамбула, Краснодонців, Лавріщева та інші: https://www.0312.ua/news/1159214 (Letöltés: 2017.09.23)

${ }^{24}$ A kruti csata 1918-ban, Krut városának közelében zajlott, az ukrán diákok és kozákok, valamint a jelentős fölényben lévő orosz bolsevik erők között. Az ütközetben, a jelentős fölény ellenére, a szovjet katonai erők visszaszorulni kényszeredtek. (A kruti csata Euromajdan utáni megítéléséról lásd részletesen: Yurchuk 2014) 


\section{TEMATIKUS TANULMÁNYOK - Kárpátalja társadalma}

talmazza - elkészítésének és felállításának költségeit az áldozatok családtagjai gyűjtötték össze. ${ }^{25}$

A dekommunizációs törvény gyakorlati végrehajtásának vizsgálatakor Ungvár esetében az állapítható meg, hogy a lokalitás, a helyi kultúra alakjairól való megemlékezés igen fontos szerepet játszott az új köztérnevek kiválasztásakor. A térség, Ungvár és Kárpátalja helyi kultúrája és történelmi eseményei elsőbbséget élveznek az országos hősök vagy események megjelenítésével szemben.

\subsection{A BEREGSZÁSZI JÁRÁS}

A magyar többségű Beregszászi járásban21 köztér átnevezése történt meg (Beregszász városa nélkül). Ezek közül 11-ről a helyi községi tanácsok döntöttek, a többiről megyei szinten, a kormányzó (Moszkal) hozott határozatot, zömében 2016-ban. ${ }^{26} \mathrm{~A}$ közterekről „száműzöttek” listájában megtalálható Tereskova (összesen négy utca), Lenin (két utca), Csapajev (két utca) vagy Karl Marx is (egy utca).

Figyelemre méltó, hogy a 21 újonnan átnevezett utcából kilenc valamely magyar történelmi személyiség vagy kimelkedő író, költő nevét kapta (pl. Zrínyi Ilona, Ady Endre, Rákóczi Ferenc). Ezek közül hat Moszkal rendelete értelmében nyerte el új, magyar vonatkozású nevét. Emellett az új utcanevek közül mindössze egy köthető kimondottan az ukrán történelemhez (Szahajdacsnij ${ }^{27}$ utca). További 9 utca etnikailag semleges nevet kapott (pl. Fő utca, Iskola utca, Erdei út), míg Bátyúban egy utca neve a település ATO-ban elesett szülöttjéről, Szerhij Kuzmenkoról került átnevezésre (ugyancsak Moszkal rendeleteértelmében).

Az adatok alapján megállapítható, hogy a Beregszászi járásban a dekommunizációs törvény gyakorlati végrehajtása során a járás népességének többségét alkotó magyar nemzetiségű csoporthoz köthető, magyar etnikai konnotációjú elnevezések jóval nagyobb arányban jelennek meg az új utcanevek között, mint az egyértelműen ukrán vonatkozásúak.

\subsection{BEREGSZÁSZ}

A többé-kevésbé kiegyenlített etnikai arányokkal jellemezhető Beregszászon hét utca és egy tér került átnevezésre, amelyekről a beregszászi városi tanács hozott

${ }^{25}$ Dеро.Закарпаття: В Ужгороді відкрили меморіал загиблим в АТО військовим: https://zak. depo.ua/ukr/zak/v-uzhgorodi-vidkrili-memorial-zagiblim-v-ato-viyskovim-29062016104800 (Letöltés: 2017.10.25.)

${ }^{26}$ Uzhgorod.net.ua: Перейменування від Москаля: у Берегові нове ім'я навіть у вулиці Свободи: http://uzhgorod.net.ua/news/92585 (Letöltés: 2017.09.19)

${ }^{27}$ Ukrán katonai vezető és politikus, a Zaporozsjei Szics kozák hetmanja. 


\section{TEMATIKUS TANULMÁNYOK - Kárpátalja társadalma}

határozatot. ${ }^{28}$ Megyei szinten csak két névadásról, a kelet-ukrajnai fronton elhunyt néhai beregszászi lakosok, Timoscsuk Mihály és Tóth Sándor köztérben való megemlékezéséről döntöttek (5. fotó) ${ }^{29}$

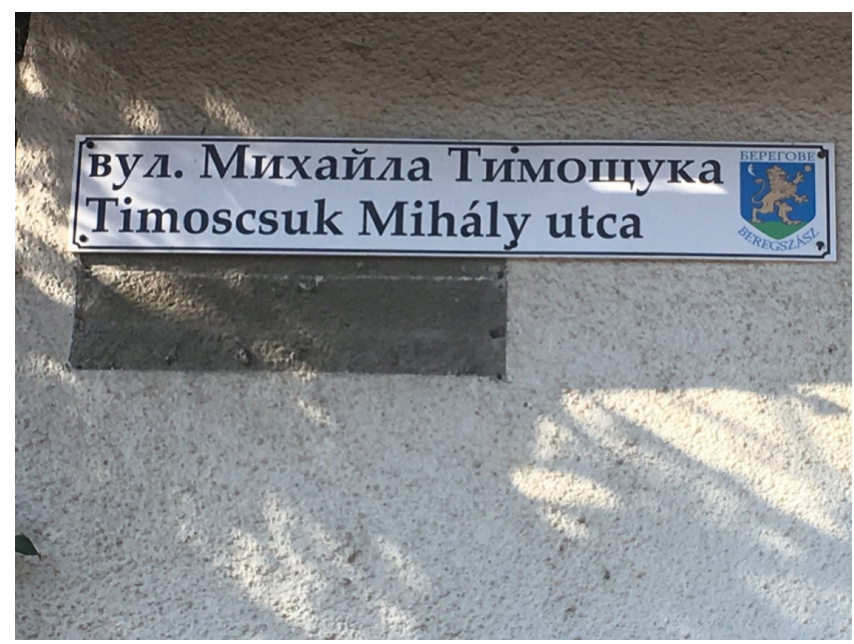

5. fotó. Timoscsuk Mihály utcanévtábla Beregszászon. Alatta még látható a korábbi utcanévtábla helye (2017. július). Fotó: Erőss Ágnes

A nyolc átnevezett utcából csak négy (Kutuzov, Szuvorov, Radhoszp, Belinszkij) tartozott azok körébe, melyeknek megváltoztatása kötelező volt a dekommunizációs törvény értelmében. További egy orosz (Puskin) ${ }^{30}$ illetve egy ukrán (Karmeljuk) ${ }^{31}$ vonatkozású, kettő pedig semleges nevet viselt (Görbe, Szabadság). Beregszász páldáján azt is érdemesnek tartjuk kiemelni, hogy négy esetben az utca az 1914 előtti, a Magyar Királyság idején viselt nevét nyerte vissza. Ezek a Széna, az Oroszlán, a Hársfa és a Rövid utcák. Ezen köztérnevek a helyi magyarok számára hordozhatnak többletjelentést, hiszen a város magyar múltjából táplálkoznak, akkor voltak hivatalosak, amikor Beregszász a Magyar Királyság része volt. Mivel jelentéstartalmukat tekintve etnikumsemlegesek, ugyan kisebb szimbolikus tőkét képviselnek, ellenben kevésbé is vitathatóak mind az ukrán, mind a magyar közösség számára. Beregszászon két

${ }^{28}$ Suprunenko 0: Міські депутати затвердили список вулиць та площ Берегова. Beregovo. today: http://beregovo.today/NewsOpen/id_news_281310 (Letöltés: 2017.09.19.)

${ }^{29}$ Uzhgorod.net.ua: Перейменування від Москаля: у Берегові нове ім'я навіть у вулиці Свободи: http://uzhgorod.net.ua/news/92585 (Letöltés: 2017.09.19)

${ }^{30}$ Orosz költő, író, drámaíró.

31 Ukrajna nemzeti hőse, nacionalista, paraszt felkelővezér. 


\section{TEMATIKUS TANULMÁNYOK - Kárpátalja társadalma}

utca az ATO helyi áldozataira emlékezik (5. fotó), míg további kettő semleges nevet kapott (Határmenti, Templom).

\section{Konklúzió}

Az Euromajdan eseményei nyomán lezajlott politikai változások együttjártak az ukrán nemzetfogalom újraértelmezésével (Kulyk 2016), amely egyrészt a szovjet/ orosz múlttól való elhatárolódással, másrészt új vagy korábban kevésbé preferált történelmi személyiségek és események előtérbe állításával törekszik körülbástyázni és a belső kohéziót növelve erősíteni az ukrán nemzeti identitást. Mindennek formai és tartalmi kereteit a 2015-ben elfogadott, a dekommunizációt elrendelő törvények szabályozzák, amelyek a szovjet múlt emlékeinek száműzése mellett az Ukrajna függetlenségéért harcoló történelmi (pl. hetmanok) vagy közelmúltbeli/kortárs személyek (pl. Mennyei Század, ATO katonák) heroizálását is célozza, így alkotva meg az ukrán nemzeti identitás új, 21. századi alapjait. Ez a kettős folyamat a hatalom köztérpolitikájában, a városok szimbolikus terében is tükröződik.

Írásunkban a dekommunizációt elrendelő törvény hatásait elemezve elsősorban az utcanevekben bekövetkezett változásokat elemeztük. Megállapítottuk, hogy mind Kijevben mind Kárpátalja vizsgált településein a köztérnevek megközelítően 5\%-a változott a rendelkezések nyomán. Ugyan a mennyiségi változások megegyeznek a főváros és a legnyugatabbi megye esetében, azonban az új köztérnevek merőben eltérő irányokról és preferenciákról árulkodnak. Amíg a főváros új köztérnevei túlnyomórészt az ukrán nemzeti történelem és kultúra szereplői mellett vitatott megítélésű politikai alakokról nyerték nevüket, addig Kárpátalján a helyi és regionális történelem, közélet, kultúra kiemelkedő személyiségei váltak névadóvá. Így az utóbbi két-három év köztérátnevezései következtében Kárpátalja-szerte immár több utca viseli Zrínyi vagy Rákóczi nevét. Beregszász esetében felhívtuk a figyelmet arra, hogy több olyan semleges jelentésű köztérnév (pl. Rövid, Széna) is visszaállításra került, amely a 19. század végén, 20 . század elején volt hivatalos, tehát a város magyar időszakához, magyar múltjához kötődik.

Az új utcanevek mellett az Euromajdani tüntetésekre illetve az ATO-ban elesettekre való emlékezés különféle formái képezik a másik jelentős átalakulást a szimbolikus térben. Kijevben az Euromajdan során elesettek, a város helyi áldozatai egyben a nemzet hősei is lesznek, a nemzeti panteon részévé válnak. A fotóikból összeállított tabló nem csupán a főváros közterein, de Kárpátalja szerte is megtalálható. Emellett azonban Kárpátalján a megye, illetve a települések helyi áldozatairól mindenhol megemlékeznek (6. fotó). A több mint $1000 \mathrm{~km}$ távolságban zajló háborúban elhalálozottak így a kárpátaljai falvak, városok áldozataivá, helyi hősökké válnak. A kelet-ukrajnai konfliktus így kialakuló helyi narratívája, lokális emlékezete ezáltal a nemzeti szint mellett, részben annak alternatívájaként is formálódik. 


\section{TEMATIKUS TANULMÁNYOK - Kárpátalja társadalma}

Kutatásaink alapján úgy véljük, hogy Kárpátalján mind a dekommunizációs törvény végrehajtása során zajló köztérátnevezések, mind az ATO helyi hőseire való emlékezés azt bizonyítja, hogy a helyi szint képes a központi emlékezetpolitikát saját képére formálni. Az adott település, régió jeles történelmi személyiségeire vagy az ATO helyi áldozataira való emlékezés révén az Euromajdan utáni, a szimbolikus tér átformálására irányuló, Kijevből elrendelt átalakulás Kárpátalján a helyi örökség részbeni újrafelfedezését, gazdagítását és köztérben való megjelenítését is lehetővé tette.

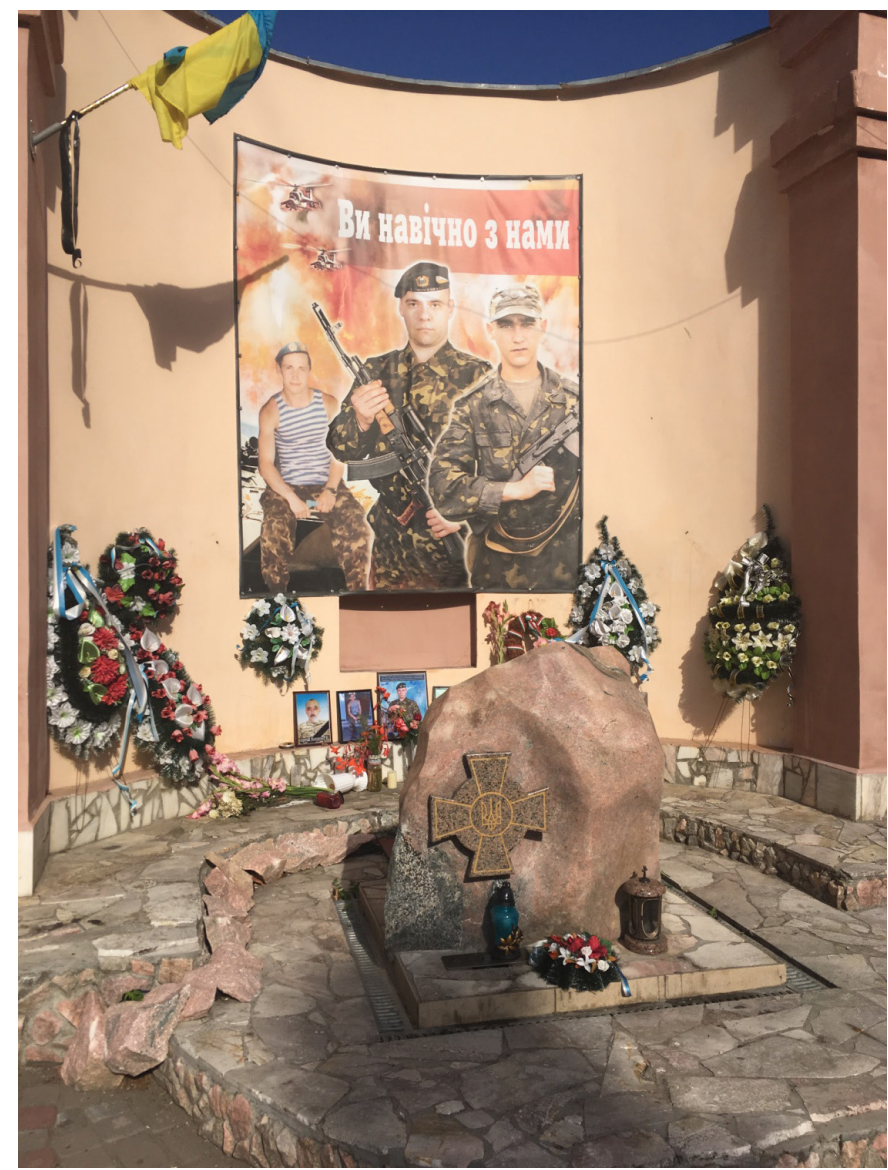

6. fotó. A Beregszászi járásból származó ATO-ban elesettek emlékműve Beregszász főterén. Fotó: Erőss Ágnes 


\section{TEMATIKUS TANULMÁNYOK - Kárpátalja társadalma}

\section{Irodalom}

Atkinson, D. - Consgrove, D. (1998): Urban Rhetoric and Embodied Identities: City, Nation, and Empire at the Vittorio Emanuele II Monument in Rome, 1870-1945. Annals of the Association of American Geographers, 88 (1): 28-49.

Azaryahu, M. (1996): The power of commemorative street names. In: Environment and Planning D: Society and Space, 14 (3): 311-330.

Azaryahu, M. (1997): German reunification and the politics of street names: the case of East Berlin. In: Political Geography, 16 (6): 479-493.

Azaryahu, M. (2009): Naming the past: the significance of commemorative street names. In: Berg L. D. - Vuolteenaho, J. (eds.): Critical toponymies: the contested politics of place naming. Ashgate, Aldershot: 53-70.

Azaryahu, M. - Kook, R. (2002): Mapping the nation: street names and Arab-Palestinian identity: three case studies. Nations and Nationalism, 8 (2): 195-213.

Barna G. (2000): Mentális határok - megduplázott világok. In: Balázs G. et al. (szerk.): Folklorisztika 2000-ben: folklór - irodalom - szemiotika: tanulmányok Voigt Vilmos 60. születésnapjára. Eötvös Loránd Tudományegyetem Bölcsészettudományi Kar, Budapest: 689-701.

Barth, F. (1969): Ethnic groups and boundaries: the social organization of culture difference. Little, Brown, Boston

Bourdieu, P. (1989): Social space and symbolic power. In: Sociological Theory, 7 (1): $14-25$.

David, J. (2013): Street Names - Between ideology and cultural heritage. In: Acta Onomastica, LIV.: 1-8.

Diener, A.C. - Hagen, J. (2013): From Socialist To Post-Socialist Cities: Narrating The Nation Through Urban Space. In: Nationalities Papers, 41 (4): 487-514.

Erőss, Á. (2018): Szimbolikus terek és térhasználat többnemzetiségű városokban: Beregszász és Nagyvárad példája. (Doktori disszertáció, elbírálás alatt)

Erőss, Á. (2016): „In Memory Of Victims”: Monument And Anti-Monument On Liberty Square, Budapest. In: Hungarian Geographical Bulletin, 65 (3): 237-254.

Erőss, Á. - Tátrai, P. (2010): Ethnic features of symbolic appropriation of public space in changing geopolitical frames: the case of Oradea/Nagyvárad. In: Hungarian Geographical Bulletin, 59 (3): 51-68.

Fedinec, Cs. - Csernicskó, I. (2016): Az Ukrajnából számúzött Lenin: Európai út a kommunizmus öröksége nélkül? In: Regio, 24(1): 73-124.

Fedince, Cs. (2016): Szalagok, hősök, szobrok. A II. világháború emlékezet Ukrajnában 1991 után. Kommentár. http://kommentar.info.hu/attachment/0001/669_ kommentar-1606-04-fedinec.pdf. (Utolsó letöltés: 2018.05.22.) 


\section{TEMATIKUS TANULMÁNYOK - Kárpátalja társadalma}

Hale, H. E. - Orttung, R. W. (2016): Beyond the Euromaidan. Comparative Perspective on Advancing reform in Ukraine. Stanford University Press

Harrison, S. (1995): Four types of symbolic conflict. In: The Journal Of The Royal Anthropological Institute, 1 (2): 255-272.

Harvey, D. (1979): Monument and Myth. Annals of the Association of American Geographers, 69 (3): 362-381.

Hobsbawm, E. (2015): Introduction: Inventing traditions. In: Hobsbawm, E. - Ranger T. (eds.): The invention of tradition. Cambridge University Press, Cambridge: $1-14$.

Jordan, P. - Klemenčić, M. (2003): Transcarpathia - Bridgehead Or Periphery? In: Eurasian Geography And Economics, 44 (7): 497-513.

Karácsonyi, D. - Kocsis, K. - Kovály, K. - Molnár, J. - Póti, L. (2014): East-West dichotomy and political conflict in Ukraine - Was Huntington right? Hungarian Geographical Bulletin, 63 (2): 99-134.

Kezer, Z. (2009): An imaginable community: the material culture of nation-building in early republican Turkey. Environment and Planning D: Society and Space 2009, 27 (3): 508-530.

Kiridon, A. (2017): Dekomunizacia v Ukraini: priroda ta sutnisth kharakteristiki protsesu (Декомунізація в Україні: природа та сутність характеристики процесу). In: M. Mihailuca (Eds.): Pivden Ukraini: etnoistorichnii, movnij, relihijnij ta kulturnii vimiri, Odessza: 157-163.

Kliot, N. - Mansfield, Y. (1997): The political landscape of partition: The case of Cyprus. Political Geography, 16 (6): 495-521.

Kobchenko K. (2016): Dekomunizacia v Ukraini: postkolonialnii aspekt (Декомунізація в Україні: постколоніальний аспект), Ukrainoznavchii almanah, 19, Kijev, 66-70.

Kozyrska, A. (2016): Decommunisation of the Public Space in Post-Euromaidan Ukraine. Polish Political Science Yearbook, 45: 130-144.

Kulyk, V. (2014): Ukrainian Nationalism Since the Outbreak of Euromaidan. In: Ab Imperio, 3: 94-122.

Kulyk, V. (2016): National identity in Ukraine: impact of Euromaidan and the war. In: Europe-Asia Studies, 68 (4): 588-608.

Kuzio, T. (1998): Ukraine. State and nation building. Routledge Studies Of Societies In Transition 9., Routledge, London, New York

Kuzio, T. (2015): Competing Nationalism, Euromaidan, and the Russian-Ukrainian Conflict. Studies in Ethnicitz and Nationalism, 15 (1): 157-169. 


\section{TEMATIKUS TANULMÁNYOK - Kárpátalja társadalma}

Light, D. (2004): Street names in Bucharest, 1990-1997: exploring the modern historical geographies of post-socialist change. In: Journal of Historical Geography, 30 (1): 154-172.

Males, L. (2016/a): Dekomunizacia stolici: zmini urbanonimii (metodi, persi rezultati) (Декомунізація столиці: зміни урбанонімії (методи, перші результати)). In: Sociolohichni doslidzhenia sutchasnoho suspilstva: metodolohia, teoria, metodi, 36, Harkiv: 62-67.

Males, L. (2016/b): Diskurs dekomunizacii v Kievi (Дискурс декомунізації в Києві). In: Sotciolohichni studii, 2 (9): Luck: 16-21.

Massey, D. (1994). Space, place and gender. University Of Minnesota Press, Minneapolis

Melchior, I. - Visser, O. (2011): Voicing past and present uncertainties: the relocation of a soviet world war II memorial and the politics of memory in Estonia. In: Focaal-Journal Of Global And Historical Anthropology, 59: 33-50.

Mitchell, D. (2003): The right to the city: social justice and the fight for public space. Guilford Press, New York

Molnár, J. - Molnár, D.I. (2005): Kárpátalja népessége és magyarsága a népszámlálási és népmozgalmi adatok tükrében. Kárpátaljai Magyar Pedagógusszövetség, Ungvár

Nadkarni, M. (2003): The death of socialism and the afterlife of its monuments. Making and marketing the past in Budapest's Statue Park Museum. In: Hodgkin, K. Radstone, S. (eds.): Contested Pasts. The Politics Of Memory. Routledge, London: 193-207.

Njoh, A. J. (2017):Toponymic Inscription as an Instrument of Power in Africa: The case of colonial and post-colonial Dakar and Nairobi. Journal of Asian and African Studies, 52 (8): 1174-1192.

Olszański, T. A. (2016): Aftermath of the Maidan. Ukrainian society two years after the revolution. https://www.osw.waw.pl/en/publikacje/osw-commentary/2016-03-04/aftermath-maidan-ukrainian-society-two-years-after-revolution (Utolsó letöltés: 2018.06.11.)

Palonen, E. (2008): The city-text in post-communist Budapest: street names, memorials, and the politics of commemoration. In: Geojournal, 73 (3): 219-230.

Palonen, E. (2012): Transition to crisis in Hungary: Whistle-Blowing On The Naked Emperor. In: Politics \& Policy, 40(5): 930-957.

Pokatayev, P. (2018): Protsesi dekomunizacii v Ukraini: sutchasni problemi ta perspektivi podalshoi realizatsii (Прицеси декомунізації в Україні: сучасні проблеми та перспективи подальшої реалізації). In: Investichii: praktika ta dosvid, 2, Kijev: 78-81. 
www. metszetek.unideb.hu

\section{TEMATIKUS TANULMÁNYOK - Kárpátalja társadalma}

Pótó, J. (2003): Az emlékeztetés helyei. Emlékművek és politika. Osiris, Budapest: 310.

Riabchuk, M. (2016): Dekomunizacia tsi dekolonizacia? Scho pokazali politischni diskusii z privodu „dekomunizaciinih zakoniv”? (Декомунізація чи деколонізація? Що показали політичні дискусії з приводу «декомунізаційних» законів?). In: Naukovi zapiski IPIEND, 82(2): 104-117.

Shveda, Y. - Park. J. H. (2016): Ukraine's revolution of dignity: The dynamics of Euromaidan. Journal of Eurasian Studies, 85-91.

Shevel, O. (2016): Decommunization in Post-Euromaidan Ukraine. Law and Practice. PONARS Eurasia Policy Memo. http://www.ponarseurasia.org/memo/decommunization-post-euromaidan-ukraine-law-and-practice (Utolsó letöltés: 2018. 05. 02.).

Till, K. (1999): Staging the Past: Landscape Design, Cultural Identity and Erinnerungs politik at Berlin's Neue Wache. Ecumene, 6 (3): 25-283.

Tsyba, V. (2017): “Dekomunizacia” i lehitimacia pravliachoi eliti v Ukrajni («Декомунізація» і легітимація правлячої еліти в Україні). In: Visnik Dnipropetrovskoho Universitetu. Seria philosophia, Sotsiolohia, Politolohia, 1(35), Dnipropetrovsk: $152-171$.

Yekelchyk, S. (2015): National heroes for a new Ukraine: Merging the Vocabularies of the Diaspora, Revolution and Mass Culture. Ab Imperio, 3: 97-123.

Yeoh, B. (1992): Street names in colonial Singapore. Geographical Review, 82 (3): 313-322.

Yurchuk, Y. (2014): Reordering of meaningful worlds: Memory of the organization of Ukrainian Nationalists and the Ukrainian Insurgent Army in post-soviet Ukraine (Phd Dissertation). In: Acta Universitatis Stockholmiensis. Stockholm Http:// Urn.Kb.Se/Resolve?Urn=Urn:Nbn:Se:Sh:Diva-25432

Van der Wusten, H. (2000): Dictators and their capital cities: Moscow and Berlin in the 1930s. GeoJournal.,52: 339-344.

Wylegała, A. (2017): Managing the difficult past: Ukrainian collective memory and public debates on history. Nationalities Papers. 45 (5): 780-798.

\section{INTERNETES FORRÁSOK:}

Andriiv B: Рішення про перейменування вулиць міста. Ужгородська міська рада: http://rada-uzhgorod.gov.ua/web/uploads/old_docs/rada/PR_pro_perejmenyv_vyluc_26.01.16.pdf (Utolsó letöltés: 2017.09.20.) 
www. metszetek.unideb.hu

\section{TEMATIKUS TANULMÁNYOK - Kárpátalja társadalma}

Dеро.Закарпаття: В Ужгороді відкрили меморіал загиблим в АТО військовим: https://zak.depo.ua/ukr/zak/v-uzhgorodi-vidkrili-memorial-zagiblim-v-ato-viyskovim-29062016104800 (Utolsó letöltés: 2017.10.25.)

Novynarnia.com: Москаль перейменував 20 вулиць на Закарпатті на честь загиблих в АТО: https://novynarnia.com/2016/04/05/moskal-pereymenuvav20-vulits-na-zakarpatti-na-chest-zagiblih-v-ato/ (Utolsó letöltés: 2016.04.05.)

Suprunenko 0: Міські депутати затвердили список вулиць та площ Берегова. Beregovo. today: http://beregovo.today/NewsOpen/id_news_281310 (Utolsó letöltés: 2017.09.19.)

Ukrán Nemzeti Emlékezet Intézet (UNEI): Список осіб, які підпадають під закон про декомунізацію: http://www.memory.gov.ua/publication/spisok-osib-yaki-pidpadayut-pid-zakon-pro-dekomunizatsiyu (Utolsó letöltés: 2017.11.15.)

Ukrán Nemzeti Emlékezet Intézet (UNEI): Як перейменувати вулицю: http://www. memory.gov.ua/page/yak-pereimenuvati-vulitsyu (Utolsó letöltés: 2017.10.10.)

Ungvár város honlapja: В Ужгороді перейменували вулиці Джамбула, Краснодонців, Лавріщева та інші: https://www.0312.ua/news/1159214 (Letöltés: 2017.09.23).Uzhgorod.net.ua: Перейменування від Москаля: у Берегові нове ім'я навіть у вулиці Свободи: http://uzhgorod.net.ua/news/92585 (Utolsó letöltés: 2017.09.19) 